\title{
Labour market positions of University of Limburg graduates
}

Citation for published version (APA):

Heijke, J. A. M., \& Ramaekers, G. W. M. (1992). Labour market positions of University of Limburg graduates. Researchcentrum voor Onderwijs en Arbeidsmarkt, Faculteit der Economische Wetenschappen. ROA Research Memoranda No. 2E https://doi.org/10.26481/umaror.199202E

Document status and date:

Published: 01/01/1992

DOI:

10.26481/umaror.199202E

Document Version:

Publisher's PDF, also known as Version of record

\section{Please check the document version of this publication:}

- A submitted manuscript is the version of the article upon submission and before peer-review. There can be important differences between the submitted version and the official published version of record.

People interested in the research are advised to contact the author for the final version of the publication, or visit the DOI to the publisher's website.

- The final author version and the galley proof are versions of the publication after peer review.

- The final published version features the final layout of the paper including the volume, issue and page numbers.

Link to publication

\footnotetext{
General rights rights.

- You may freely distribute the URL identifying the publication in the public portal. please follow below link for the End User Agreement:

www.umlib.nl/taverne-license

Take down policy

If you believe that this document breaches copyright please contact us at:

repository@maastrichtuniversity.nl

providing details and we will investigate your claim.
}

Copyright and moral rights for the publications made accessible in the public portal are retained by the authors and/or other copyright owners and it is a condition of accessing publications that users recognise and abide by the legal requirements associated with these

- Users may download and print one copy of any publication from the public portal for the purpose of private study or research.

- You may not further distribute the material or use it for any profit-making activity or commercial gain

If the publication is distributed under the terms of Article $25 \mathrm{fa}$ of the Dutch Copyright Act, indicated by the "Taverne" license above, 


\section{LABOUR MARKET POSITION OF \\ UNIVERSITY OF LIMBURG GRADUATES}

ROA-RM-1992/2E

J.A.M. Heijke, G.W.M. Ramaekers*

A contribution to the European Symposium on Labour Market Developments, Scarman House,

University of Warwick, 21st \& 22nd May 1992

\section{RESEARCH CENTRE FOR EDUCATION AND THE LABOUR MARKET}

Faculty of Economics and Business Administration

Rijksuniversiteit Limburg

Maastricht, February 1992

* The authors are attached to the Research Centre for Education and the Labour Market (ROA) at the University of Limburg. They are indebted to dr. R.K.W. van der Velden, also attached to ROA, for supervising the research and for his comments on an earlier version of this paper. 
CIP-GEGEVENS KONINKLIJKE BIBLIOTHEEK, DEN HAAG

Heijke, J.A.M.

Labour market position of University of Limburg graduates / J.A.M. Heijke, G.W.M. Ramaekers. - Maastricht: Research Centre for Education and the Labour Market, Faculty of Economics and Business Administration, Rijksuniversiteit Limburg. - (ROA-RM-1992/2E)

Met lit. opg.

ISBN 90-5321-082-2 in spiraalband

Trefw.: arbeidsmarkt; academici; Nederland. 


\section{CONTENTS}

1. INTRODUCTION 1

2. STRUCTURE OF THE LABOUR MARKET SCANNER 3

3. THE UNIVERSITY OF LIMBURG

4. RESPONSE, BY FIELD OF STUDY 7

5. UNEMPLOYMENT BEFORE ENTERING THE FIRST JOB 9

6. CURRENT POSITION 14

7. SOME POLICY IMPLICATIONS 28

$\begin{array}{ll}\text { REFERENCES } & 30\end{array}$ 


\section{SUMMARY}

This paper relates to the first application of the labour market scanner in the university of Limburg. With this scanner the labour market position and the careers of the graduates can be periodically mapped out and information can be obtained about the match between the academic disciplines studied by graduates and their occupations and about any further studies undertaken after graduation.

The first application of the labour market scanner relates to students who graduated in the years 1986 up to 1989. As of 1991, the previous year's graduates will be surveyed every year, and information on earlier students will be updated from year to year.

This paper will begin with an explanation of the contents and set-up of the labour market scanner, followed by a presentation of the recent results of the first application. The results discussed relate to the duration of graduates' unemployment before gaining a job and to some aspects of the positions they currently hold such as the work region, the sector of industry, occupation, management functions, income, the required education level and potential job mobility. Finally, we indicate some fields in which these research findings allow policy to be developed. Among other things, we will argue for the national application of the labour market scanner. 


\section{INTRODUCTION}

There are several reasons why it is important to have information on the labour market position of graduates. One reason is that (prospective) students (and their parents) increasingly want to know what the chances are of getting work with a given qualification, what occupations can be practised with that education, what income can be earned in those occupations and what the expected later career path is. Another reason is that a good match between education and the labour market is important for quality control in higher education. For the benefit of the external examination commissions' evaluations of academic studies, it is needed to ascertain students' destination and what degree of unemployment there is among them, and to ask them, among other things, for their opinion of their education and what demands employers make on them. Information on the labour market position of graduates is also important for organizations concerned with labour exchange. In seeking to achieve a good match between demand and supply on the labour market, they want to be informed about the rate at which graduates are admitted to the labour market, the way they find a job and the posts in which they end up. This information can provide them with insight into the need for intermediation activities and whether training programmes or other measures should be undertaken to improve the job match.

The labour market information required for the information and policy goals mentioned above is, however, not available. The data from the Labour Force Survey (EBB) of the Central Bureau of Statistics (CBS) are too general for an analysis of the labour market position of graduates from specific disciplines. The data on registered unemployment are rather detailed, but also badly contaminated. Many of the registered unemployed should not be registered, and a large number are incorrectly excluded from the register.

In an earlier paper (Heijke, 1990) and elsewhere (Van Dam, Heijke and Ramaekers, 1990), it was said that educational institutions themselves can fill this information gap by regularly surveying the labour market position of their graduates. If uniform definitions and classifications were used that conform to the internationally accepted method used by the CBS, aggregation of the data from each institution would produce usable statistics and a source of data suitable for analysis. Such a data source would be both directly (statistically) and indirectly (analytically) useful for offering guidance and making policy. Monitoring the labour market position of the graduates would produce not only research data, but also an up-to-date address file of former students and their employers. For educational institutions, this file could be the basis for a range of activities relating to graduates and employers, such as offering post-graduate education to target groups, fund-raising, distributing a magazine or giving their institution a distinctive profile in education and research.

There have already been some initiatives in this field. The first concerns secondary level 
education, where, through the so-called RUBS-survey, ${ }^{1}$ school leavers are questioned about their position in (continued) education or on the labour market. ${ }^{2}$ Recently a second initiative was started relating to Higher Vocational Education (HBO), also limited to the position of graduates one year after their graduation. This "HBO-monitor" covers a considerable portion of the HBO training varieties. The third initiative to be mentioned here concerns academic education. On the basis of national and international examples, the Research Centre for Education and the Labour Market (ROA) has developed a labour market scanner for universities, with which the graduates are followed during their entire working life, beginning one year after their graduation. ${ }^{3}$

The labour market scanner has now been introduced at the University of Limburg (RL). In the course of 1990 , ROA surveyed the graduates from the period 1986 - 1989. Part of this work was catching up with the graduates of earlier years. As of 1991, the graduates of each year will be questioned about one year after graduation and information on earlier graduates will be updated each year. The structure of this labour market scanner and some results from its first application will be presented below. The paper concludes with some policy suggestions resulting from the research findings. ${ }^{4}$

1. RUBS stands for Registration of the Outflow and Destination of School leavers (in Dutch).

2. For a description of RUBS, see De Grip and Van Dam (1989).

3. Van Dam, Heijke and Ramaekers (1989).

4. For a complete report on the structure and results, see: Ramaekers and Heijke (1991). 


\section{STRUCTURE OF THE LABOUR MARKET SCANNER}

The labour market scanner of the RL consists of two instruments. The first is the basic questionnaire, used to survey all former students approximately one year after their graduation. Personal data are asked for; data on the education concluded, preparatory education, labour experience before graduation and principal activities after graduating up to the moment of the survey; the current labour market position and, for those in a paid job, some characteristics of the position they hold and of the organization; whether they are looking for another (paid) job and whether they have undertaken training after graduation.

The second instrument is the annual questionnaire. This is sent yearly as a follow-up to the basic questionnaire. It is a condensed version of the basic questionnaire. With this form the respondent can report changes in his or her labour market position over the past year, for instance a change of job.

In constructing the questionnaires, we began with the principle that it must produce data which can be compared with other data sources, such as the Labour Force Survey from the CBS. This meant that the data would have to be gathered in a scientifically sound manner and would have to conform to nationally and internationally used definitions of concepts such as employment and unemployment, and to national and international classifications of education types, occupations and sectors of industry.

The methodology employed allows the yearly questionnaire to be supplemented every five years with more detailed questions about labour mobility, ongoing career path and any other topics relating to the match between education and the labour market which one might wish to examine.

One vital factor in the research is the address file. For the RL study, the addresses were obtained through the central student administration. Because of the high chance of there having been changes of address, the questionnaire was sent to the parents, unless a recent address of the former student was available through his faculty. If the parental address appeared to have changed, the new address was traced through the telephone directory. After some weeks, a second mailing was directed to those who had not yet reacted. If there was still no reaction the former student was contacted by telephone and urged to participate in the survey.

An up-to-date address file of former students was thus obtained, which will form the basis for the yearly up-dating of labour market data. Moreover, the file can be used for all sorts of other forms of communication between the university and its graduates. It is even recommended that an alumni policy should be implemented, because this will work both ways. The address file updated for the research will allow the university to communicate with graduates at regular times and this in itself will contribute to the up-dating of the address file for the next round of research. The address file is kept apart from the response file obtained from the survey for reasons of privacy. 
$-4-$

The constant up-dating of the address file is vital for the research, because otherwise the file would rapidly shrink to an insufficiently representative whole. The efforts to obtain an up-todate file described above were rewarded with a very high response, of $81 \%$. But it should not be forgotten that a loss factor in the file as a result of inevitable non-responses of say $20 \%$ per year would, after five years, leave only $33 \%$ of the original file. Therefore the yearly update survey is sent to the whole cohort, including those who did not participate before. 


\section{THE UNIVERSITY OF LIMBURG}

The RL is the youngest university of the Netherlands. The institution consists of five faculties: medical sciences (MS), health sciences (HS), science of law (LS), economic sciences (ES) and general sciences (GS).

Education at the medical faculty started in September 1974. As is the case at the other medical faculties, the students first take a four-year course for the Master's exam and then a two-year training for the final examinations in medicine.

In September 1980 education in the discipline then called social health sciences started with three main subjects: policy and management of health care services (PM), health information and education (HIE), and nursing science (NS). In 1984 the number of subjects in which students could graduate (majors) was extended with four new disciplines: movement sciences, biological health science, philosophy and theory of health sciences, and mental health science, and the educational field of social health sciences was renamed health sciences.

The faculty of law has, from the start of education in September 1982, provided courses leading to graduation in Dutch Law (full-time as well as part-time) and as of September 1990 also in fiscal law.

Education at the faculty of economics started in September 1984. The initial course in economics consists of a basic one and a half years, which is the same for all students. After that, the students can choose from a master's with a free mix of subjects or may specialise in one of four majors: general economics (GE), business economics (BE), quantitative economics (OE) and, as of February 1988, international management (IM).

As of September 1991, the general sciences faculty has offered courses in the field of culture and science studies.

The still very recent development of the educational offering at the $\mathrm{RL}$ is reflected in developments in the student intake. The intake increased in the period 1983-1990 from 557 to 1774 students per year. This growth applied to all faculties, with the exception of the medical faculty, where the inflow stabilized at about 150 students per year because of an intake quota.

Table 1 sketches the changes in the outflow which, matching changes in the intake, has also strongly increased, though the absolute figures are much lower because of students delaying study or dropping out. 
-6-

Table 1. Numbers of RL graduates, $1986-1989$

\begin{tabular}{|c|c|c|c|c|}
\hline & 1986 & 1987 & 1988 & 1989 \\
\hline Physicians & 75 & 83 & 115 & 116 \\
\hline Health scientists & 92 & 92 & 127 & 141 \\
\hline Lawyers & 61 & 122 & 165 & 127 \\
\hline Economists & -- & -- & 17 & 29 \\
\hline Total & 228 & 297 & 424 & 413 \\
\hline
\end{tabular}

Source: Central Student Administration RL 


\section{RESPONSE, BY FIELD OF STUDY}

In 1990, the students of the previous four years were comprehensively approached. Those who had graduated in the period January 1986 to June 1988 were approached with an adapted basic questionnaire, asking them to outline their career path retrospectively. Those who graduated in the second half of 1988 and the class of 1989 were surveyed with the standard basic questionnaire.

Table 2 gives an overview of the responses, divided according to faculty. The first point in this analysis is that 1100 of the 1362 graduates participated in the survey, producing the $81 \%$ response rate already mentioned. The response of the former law students was the lowest $(72 \%)$. The number of graduate economists is very limited: of the 46 approached, 42 participated in the research. Efforts to maximize the response continue.

Table 2. Representativeness of the surveys by faculty (state of the response at 15-3-1991)

\begin{tabular}{lrrrrr}
\hline Faculty & & & & & \\
& & Graduates & \multicolumn{2}{c}{ Respondents } & Response \\
& Abs & $\%$ & Abs & $\%$ & $\%$ \\
\hline MS & 389 & 29 & 330 & 30 & 85 \\
HS & 452 & 33 & 385 & 35 & 85 \\
LS & 475 & 35 & 343 & 31 & 72 \\
ES & 46 & 3 & 42 & 4 & 91 \\
Total & 1362 & 100 & 1100 & 100 & 81 \\
\hline
\end{tabular}

Source: ROA

Since the medical faculty has no specific 'major' subjects, and in the faculty of law it is only students of Dutch Law who have graduated thus far, the majors in which former students graduated are only indicated for the faculties of health sciences and economic sciences.

Of the health science graduates surveyed, $34 \%$ graduated in policy and management of health care services, $23 \%$ in health information and education, and $20 \%$ in nursing science. In terms of their numbers of graduates, the four other subjects are considerably smaller. Of the surveyed health scientists, $8 \%$ graduated in movement sciences, $7 \%$ in biological health science, $7 \%$ in mental health science and only $1 \%$ in the philosophy and theory of health sciences. Because of these small number, these four majors will be considered together throughout the remainder of this article.

The vast majority $(90 \%)$ of the economists questioned graduated in business economics. Only 
$-8-$

$10 \%$ graduated in general economics. In the two other subjects (quantitative economics and international management), no students had as yet graduated.

More than half of the surveyed graduates are women; the Faculty of Health Sciences has the highest percentage of female graduates and the Faculty of Economic Sciences the lowest. Despite their nominal study duration of six instead of 4 years, physicians are in general only 0.7 years older than the other graduates. It should be observed here that more of the graduates of the other faculties graduate at an older age, because they had often already completed a higher vocational or academic education before starting study at the RL. A little more than half of the graduates has extra qualifications in the form of paid work experience, usually as a student assistant. This is the case for economists in particular. A good one third of the graduates has extra qualifications in the form of managerial experience. 


\section{UNEMPLOYMENT BEFORE ENTERING THE FIRST JOB}

As is the case for other groups of school leavers, recently graduated academics' entry to the labour market is strongly determined by the general situation regarding demand for and supply of academics. Within this general framework, academics' labour market entry in the second half of the eighties was determined in particular by two developments. In the first place by the growth in the number of academically educated people entering the labour market, an acceleration due to the simultaneous graduation of the last cohorts of graduates who followed the 'old style' program of six years and - as of 1986 - the first cohort of 'first phase' graduates who followed the 'new style' program of four years. In the second place, as a result of economies in the government sector, the traditional source of employment for academics, it has became "less self-evident that academics could acquire a job at academic level, a fixed contract with good future prospects and a high income" (according to Van Nieuwenhuysen and Wielers, 1990 , p. 6). The labour market position of the RL graduates should be seen against the background of this general labour market situation for academics.

The labour market position of graduates will be explained first of all in terms of the subject in which they majored. It is also plausible that graduation alternatives within a major subject could have strongly differing labour market positions, and graduates' success on the labour market also depends on a number of individual background characteristics. Therefore these factors will also be taken into account.

Table 3. The portion of graduates in paid work during the first year after graduation, by faculty and by sex (in \%)

\begin{tabular}{|c|c|c|c|c|c|c|c|}
\hline \multirow[b]{2}{*}{ Period after graduation } & \multirow[b]{2}{*}{ MS } & \multicolumn{2}{|c|}{ Graduates } & \multirow[b]{2}{*}{ ES } & \multirow[b]{2}{*}{ man } & \multirow[b]{2}{*}{ woman } & \multirow[b]{2}{*}{ Total } \\
\hline & & HS & LS & & & & \\
\hline $\begin{array}{l}\text { First month after graduating/ } \\
\text { quarter of graduation }\end{array}$ & 36 & 38 & 33 & 76 & 40 & 36 & 38 \\
\hline $\begin{array}{l}\text { Third month after graduating/ } \\
\text { first quarter after graduating }\end{array}$ & 55 & 49 & 39 & 83 & 50 & 48 & 49 \\
\hline $\begin{array}{l}\text { Sixth month after graduating/ } \\
\text { second quarter after graduating }\end{array}$ & 70 & 58 & 48 & 88 & 57 & 62 & 60 \\
\hline $\begin{array}{l}\text { Twelfth month after graduating/ } \\
\text { fourth quarter after graduating }\end{array}$ & 80 & 70 & 60 & 95 & 69 & 72 & 71 \\
\hline
\end{tabular}

Source: ROA

The first element of the labour market position to be examined is the rate at which graduates can be absorbed in the labour market. The pattern of entry to the labour market is shown in 
table 3, which gives the share of all the graduates of each of the years examined who had a paid job immediately upon graduating, three months after graduating, six months after graduating and one year after graduating. The share of those with paid work is split up first according to faculty and then by sex.

Entry to the labour market appears to be rather slow at first, except for economics graduates. Three months after graduating less than $50 \%$ of the graduates had paid work, increasing rapidly to $60 \%$ six months after graduating and $71 \%$ one year after leaving the RL. The increasing proportion with paid work over the first year after graduation holds for all faculties, but in significantly dissimilar ways. Immediately after graduating the economists have a favourable head start in the labour market. Therefore the later increase in the proportion in paid work can only be small. For health scientists and especially lawyers the labour situation in the first year after graduation is disturbing. The rate of increase of paid employment for health scientists and lawyers is insufficient to compensate for their relatively great disadvantage on the labour market shortly after graduation. As a result, the proportion of health scientists and lawyers in paid employment one year after graduating is clearly lower than that among physicians and economists. The shares according to sex do not differ significantly at the measurement intervals we have used.

As was observed above, the general situation in the labour market which confronts entering academics can differ from one year to another. We examined whether the pattern of entry to the labour market differed with the year of graduation. It appeared that entry to the labour market became more and more difficult for the cohorts of 1986, 1987 and 1988. The portion of graduates who succeeded in finding paid work in the first year after graduating decreased steadily in these cohorts. It certainly looks as if the situation on the labour market with which recently graduated academics are confronted has deteriorated in this period. After 1988 some improvement seems to occur in this situation. The year-by-year decrease in the percentages in paid employment at the four measurement intervals seems to change to a slight increase with the cohort of ' 89.

The length of unemployment before entering the first job may also be determined by factors other than the field of study and sex. In order to determine the influence of graduates' other personal characteristics, the individual unemployment durations have been subjected to a closer analysis. However, in studying recent graduates' period of unemployment before they find their first paid job, there is the problem that not everyone has succeeded in finding a job at the moment of questioning. The incomplete unemployment period for a part of the population makes it difficult to determine the average unemployment duration. To overcome this problem, the uncompleted unemployment phase has to be estimated.

One possibility is to construct and estimate an explanatory model of unemployment duration. In such a model the chance of escaping unemployment, given the period that a person has already been unemployed, is explained on the basis of a number of personal characteristics and the characteristics of his or her environment, such as the situation on the local labour market. This 
assumes that these characteristics produce a shift in the basic distribution (the 'base-line') of the unemployment duration. Here, a priori, an explicit choice has to be made about the shape of this basic distribution.

Another possible approach is to estimate the expected unemployment duration using the semiparametric estimation method. This requires no explicit decisions as to the basic distribution of the conditional escape chance, the 'hazard', ${ }^{5}$ but does require prior decisions on the influence of the explanatory variables on the basic distribution. Knowledge of the exact pattern of the distribution of the hazard over time is, for our purposes, less relevant than knowledge about the influence of the exogenous variables, so the model is estimated on the basis of a partial probability, that is, the probability with respect to a random baseline hazard. This is called the 'proportional hazards' model (Cox and Oakes, 1984). It is this model which we used for our duration analysis.

In estimating the duration model, 25 cases from the total data file on 1100 graduates were left out, because the unemployment duration could not be determined. Also all unemployment durations that ended in military service were left out, because in these cases the differences in unemployment duration cannot be explained by differences in personal characteristics. In the end, 1018 persons were left for the analysis.

The explanatory variables distinguished in the analysis are dummy variables, with the exception of age and age squared (age 2). The dummies relate to paid work experience (work 1), student assistantship (work 2); work experience in the field of study (work 3); work experience outside the field (work 4); managerial experience (management); male sex (sex); preparatory education at higher vocational or academic level (preparatory education); the health science subjects biological health science, mental health science, movement sciences or philosophy and theory of health sciences (other HS); health science subject policy and management of health care services (PM); health science subject health information and education (HIE); health science subject nursing science (NS); the field of economics (economics); the field of law (law); and graduation year $(1987,1988$ or 1989).

The estimation results are given in table 4. The results - as observed above - reflect the influence of the individual characteristics of the graduates on the probability of escaping from the situation of unemployment (the 'hazard'). The first column gives the explanatory variables, the second column the estimated coefficients and the figures in the third column can be interpreted as t-values. A positive coefficient means that the characteristic in question leads to a higher chance, given that a person has already been unemployed for a certain time, of escaping that situation. That characteristic therefore has a favourable effect on the

5. The 'hazard' is the conditional exit chance, the chance that, given the fact that the individual was unemployed at time $t$, the individual will cease to be unemployed in the coming period $(t+d t)$. The term 'hazard' points to the original formulation of the theory in the field of medical statistics, where it concerns the chance that, given the fact that the patient was alive at time $t$, the patient will die in the period $t+d t$. 
unemployment duration. It should be mentioned that those leaving the group of post-graduation unemployed to return to full-time education can in some cases represent hidden unemployment. When the prospects on the labour market for graduates from a certain field of study are very bad, some will decide to continue full-time education while waiting for a possible job. Since this probably does not apply for all cases where full-time education is undertaken after graduation, no correction can be made for it in the estimation. A priori it is also not clear in which direction this will distort the estimation results.

Table 4. Estimation results from the unemployment duration model

\begin{tabular}{lcc}
\hline Variable & Coefficient & t-value \\
\hline & & -2.37 \\
age & $-0.1159^{*}$ & 2.26 \\
age2 & $0.0015^{*}$ & 1.08 \\
work1 & & 1.45 \\
work2 & 0.1464 & 1.15 \\
work3 & 0.1569 & 0.56 \\
work4 & 0.1337 & 2.17 \\
management & 0.0658 & -0.62 \\
sex & $0.1485^{*}$ & 2.22 \\
prep. education & & -2.30 \\
other HS & -0.0435 & -2.92 \\
PM & $0.2271^{*}$ & -3.85 \\
HIE & & -0.40 \\
NS & $-0.3013^{*}$ & 0.21 \\
economics & $-0.3320^{*}$ & -1.91 \\
law & $-0.5315^{* *}$ & -0.54 \\
1987 & $-0.0552^{*}$ & -0.60 \\
1988 & 0.0370 & 1.61 \\
1989 & $-0.1700^{*}$ & \\
\hline
\end{tabular}

LOG LIKELIHOOD $=-6131.3131$

GLOBAL CHI-SOUARE $=69.09 ;$ D.F. $=18 ;$ P-VALUE $=0.0000$

* significant at $5 \%$ level

** significant at $1 \%$ level

From the results it appears that age has a significantly negative influence on the hazard (somewhat corrected by age squared), that is it leads to longer unemployment before entering the first job. The influence of sex is not important.

Graduates who hold extra qualifications, whether from higher vocational education or university, or in the form of managerial experience, appear to be unemployed for a significantly shorter time after graduation. All forms of paid work experience, acquired before or during study at the $\mathrm{RL}$, have a positive influence on the hazard, but not at a significant level. 
The coefficients of the variables relating to the field of studies or, in the case of health sciences, the major subject, indicate the influence of the hazard, as compared to the training for physician, which was chosen as a basis of comparison. Compared to this reference point, the main subjects within the health sciences, health information and education, policy and management of health care services and 'Other HS', score significantly lower. Graduates majoring in these subjects therefore take longer in finding a job. The other subject specified for graduating in health sciences, nursing science, scores lower than the physician training, but this effect is not significant. The study of economics scores higher, but not significantly higher, and the study of law scores (almost significantly) lower than the physician. The study of law scores less unfavourably as regards unemployment duration than the health sciences studies of 'Other $\mathrm{HS}^{\prime}$, policy and management of health care services and health information and education. The strongly unfavourable position of the study of law initially observed in table 4 can therefore apparently be explained by characteristics other than the training chosen.

It has been noted already that the labour market situation which confronts graduates can differ from one year to another because of changes on both the demand and the supply side. Therefore the year of graduation was also entered as an explanatory variable in the estimation, which showed the last year (1989) scoring better than the reference year of 1986 . This effect, although it is not significant, would confirm the supposition mentioned above that the labour market for newly graduated academics is recovering after some difficult years. It may be that the unfavourable effect of the simultaneous entry to the labour market of the last cohorts of 'old style' graduates and of the first cohorts of 'first phase' graduates has worked itself out. 


\section{CURRENT POSITION}

Region

Table 5, in which the distribution of the graduates according to the regions in which they work has been indicated, shows that a substantial portion end up on the Limburg labour market. A vast majority work in the province of Limburg, especially in the southern part of the province (about one quarter are working in Maastricht). Despite the Euro-regional position of Maastricht, only one in every twenty former RL students works abroad.

Table 5. Region in which the current position is exercised (in \%)

\begin{tabular}{|c|c|c|c|c|c|}
\hline \multirow[b]{2}{*}{ Region } & \multicolumn{5}{|c|}{ Graduates } \\
\hline & MS & HS & LS & ES & Total \\
\hline Maastricht & 25 & 22 & 32 & 35 & 26 \\
\hline Other South Limburg & 21 & 14 & 29 & 19 & 21 \\
\hline Other Limburg & 9 & 5 & 9 & 3 & 8 \\
\hline Other provinces & 34 & 55 & 29 & 43 & 41 \\
\hline Abroad & 11 & 3 & 2 & & 5 \\
\hline Total n (=100\%) & 293 & 327 & 245 & 37 & 902 \\
\hline
\end{tabular}

Source: ROA

Of all alumni, lawyers are the most likely to end up on the Limburg labour market $(70 \%)$. Health scientists and economists are comparatively more likely to be found on the national labour market and physicians, as compared to graduates from other fields, most often end up abroad (in particular in connection with development aid). The fact that lawyers are strongly connected to this small regional labour market, may be an explanation for their long unemployment before entering the first job. Among the health scientists, the policy and management of health care services graduates in particular gravitate to the national market $170 \%$ work in provinces other than Limburg). For former nursing science and health information and education students the percentage who are working outside of Limburg is lower, at $51 \%$.

\section{Sector of industry}

From table 6, in which the graduates from each field of study are divided according to sector of industry, it can be seen that physicians and health scientists are almost entirely dependent on the non-profit service sector (especially health services). The vast majority of the lawyers end up in the service sector, either profit-seeking or non-profit (in particular judicial services, and public administration and universities, respectively). The main source of employment for economists is from commercial services (in particular accountants' offices), with non-profit services and industry an almost equal second. 
Table 6. Paid working graduates by sector of industry (in \%)

\begin{tabular}{|c|c|c|c|c|c|}
\hline \multirow[b]{2}{*}{ Sector of industry } & \multicolumn{5}{|c|}{ Graduates } \\
\hline & MS & HS & LS & ES & Total \\
\hline Industry & 2 & 5 & 5 & 21 & 5 \\
\hline Trade, hotel and catering & 0 & 1 & 5 & 0 & 2 \\
\hline $\begin{array}{l}\text { Banking and insurance, } \\
\text { profit-seeking service sector }\end{array}$ & 1 & 9 & 42 & 45 & 17 \\
\hline Non-profit service sector & 97 & 83 & 48 & 29 & 76 \\
\hline Other sectors & 0 & 1 & 1 & 5 & 1 \\
\hline Total $n(=100 \%)$ & 303 & 334 & 258 & 38 & 933 \\
\hline
\end{tabular}

Source: ROA

As for the size of the employing organization, most graduates are with companies or institutions of more than one hundred employers. Small companies of less than ten employers are of little importance. Economists in particular often end up working in large organizations. Physicians and lawyers are slightly more often to be found in small organizations, such as general practices and legal offices.

\section{Occupation}

Table 7 indicates the occupational sector in which the alumni were found. The table shows that most of them exercise a scientific function or other professional specialisation. Physicians work almost exclusively in this type of function. Health scientists also end up in managerial functions. Lawyers and economists also work in administrative functions.

Table 7. Paid working graduates by occupational sector (in \%)

\begin{tabular}{|c|c|c|c|c|c|}
\hline \multirow[b]{2}{*}{ Occupational sector } & \multicolumn{5}{|c|}{ Graduates } \\
\hline & MS & $\mathrm{HS}$ & LS & ES & Total \\
\hline Academic and other & & & & & \\
\hline specialist functions & 98 & 76 & 75 & 53 & 82 \\
\hline Executive and higher & & & & & \\
\hline Management functions & 1 & 16 & 4 & 8 & 8 \\
\hline Admin. functions & 0 & 5 & 16 & 39 & 8 \\
\hline Sales functions & 0 & 3 & 3 & 0 & 2 \\
\hline Service functions & 0 & 1 & 1 & 0 & 1 \\
\hline Total $n(=100 \%)$ & 303 & 331 & 256 & 38 & 928 \\
\hline
\end{tabular}


The belief that there is a direct and exclusive relation between education and occupation has been strongly criticized (Van Hoof and Dronkers, 1980). This naive model of the labour market erroneously ignores the flexibility to be found in the relation between education and occupation. Graduates with a certain education can end up in entirely different occupations and many occupations are practised by graduates with an entirely different educational background. The naïve model implies that a better match between education and the labour market can be established by perfectly coordinating the education given to the potential labour supply to the qualifications that are demanded on the labour market. According to the flexibility model proposed by Van Hoof and Dronkers, a broadening of the qualification profile of graduates is a much better means of improving the match between education and the labour market. Thus it is very important to have an indication of the flexibility which the various types of education offer to graduates.

One criterion which gives an indication of the flexibility in the labour market is the GiniHirschman coefficient (Sheldon, 1985; Warnken, 1986). On the basis of this criterion the occupational dispersion of the various fields of study can be determined. The formula of the Gini-Hirschman coefficient (SOB) is as follows:

$$
S O B_{k}=\left(1-\sum_{i=1}^{I} \gamma_{k i}^{2}\right) \frac{I}{I-1}
$$

where:

$$
\begin{array}{ll}
\gamma_{k i} & =\text { share of study } \mathrm{k} \text { working in occupation } \mathrm{i} \\
I & =\text { number of occupations }
\end{array}
$$

Some correction is made for the aggregation level chosen by means of the correction term $I /(I-1)$.

The big advantage of this indicator is that it is very easy to interpret. The indicator can have values between 0 and 1 . The occupational dispersion of a study is 0 if it occurs only in one occupation and 1 if the study is equally spread over all occupations. The situations of an exclusive relation between a study and occupation (the 0 coefficient) and of full flexibility (the 1 coefficient) can be seen as archetypical extremes. It is however probably that most occupations and studies are in fact located far from these extremes (De Grip and Heijke, 1989).

Table 8 shows the SOB coefficients for occupational dispersion of the fields of study distinguished at the $\mathrm{RL}$, calculated with formula (1). In calculating the dispersion indicator, occupational groups (i.e., classified at the 3-digit level of the CBS classification of occupations) were used. It should also be mentioned that the coefficients are inclined to rise rapidly and thus to suggest a large dispersion. The reason for it is that the coefficients will be higher when the occupations are less aggregated, because the number of occupations in which graduates of a 
given field of study can be found is greater at a lower aggregation level. The correction term adopted in the formula does not entirely correct for this. Therefore no absolute importance can be attributed to the value of a calculated dispersion indicator. It provides a basis for comparison between the field of study and other RL studies and thus says something about the relative dispersion over the usually limited number of occupations practised with a certain study. In interpreting the dispersion indicators presented here it should also be kept in mind that these relate not to the potential flexibility, but to the flexibility actually found among former RL students.

Table 8. The occupational group dispersion and the unemployment rate for fields of study/major subjects at the RL

Study

SOB

1) 21 3) $\quad \begin{array}{r}\text { unemployed } \\ \text { respondents }\end{array}$

\begin{tabular}{lrrrr} 
Medicine & 0.19 & 0.26 & 0.27 & 4 \\
PM & 0.80 & 0.84 & 0.89 & 5 \\
HIE & 0.61 & 0.69 & 0.72 & 9 \\
NS & 0.80 & 0.84 & 0.89 & 5 \\
Law & 0.73 & 0.75 & 0.78 & 18 \\
Economics & 0.67 & 0.78 & 0.75 & 5 \\
\hline
\end{tabular}

Source: ROA

1) Specific study required

2) Also non-specific branches of study allowed

3) Also education below academic level allowed

In column 3 of the table it can be seen that the dispersion coefficient for medicine is clearly lower than for other studies. The SOB coefficient for this study indicates a relatively low occupational dispersion. The major subjects policy and management of health care services and nursing science on the other hand have high occupational dispersions. Economics, law, and health information and education occupy a position in between. In short, the relation between education and occupation comes closest to the naive model for physicians and closest to the flexibility model for former students of the policy and management of health care services and nursing science. On the basis of the calculated results it can be concluded that the relation between education and occupation for lawyers, economists and health information and education graduates certainly does not match the naïve model but neither is there complete flexibility.

The dispersion coefficients given in column 3 were calculated on the basis of all of the occupations which former students practice. The training requirements of jobs held outside the 
graduates' immediate field of study were not taken into account. It is obvious that a graduate who at first cannot find a job that corresponds with his or her study will accept a job that fits less well. The mismatch then created may relate to the field and/or the level of the job. However, if one wants to make a statement about the alternative possibilities on the labour market for the various studies, the functions for which the study concerned is not specifically required should be left out. To get an idea of this, the occupational dispersion of the studies is also determined by first looking only at functions for which a study at academic level is required and then at functions for which the specific academic study concerned is a requirement. The dispersion indicators calculated in this way are given in columns 2 and 1 respectively.

The dispersion coefficients for the different fields of education are indeed smaller when, in the domain concerned, the functions link up better with the study taken. As these differences grow bigger, the graduates of the study concerned who cannot find an occupation within the occupational domain for which they were specifically educated will more often be able to switch to occupations that link up less well with the direction and level of the study they took. However the differences between the three types of dispersion coefficients hardly vary from one field of study to the other. The relatively largest alternative possibilities outside their specific occupational domain appear to be for health information and education graduates and the smallest for law graduates.

In table 8 the unemployment percentages among the surveyed former students for each field of study or major subject concerned are also indicated. The unemployment rate and the dispersion coefficient can correlate in two, opposite, ways. In the first place, a high dispersion coefficient can indicate ample alternative possibilities, as a result of which unemployment for the field of study concerned will be low. The correlation between the two indicators will in this case be negative. However, the opposite chain of reasoning can also be used: high unemployment in a certain field gives rise to a larger degree of dispersion, because school leavers who cannot find a job in their 'own' occupational domain try to find work in other occupations. In this case there is a positive correlation between the two indicators.

In figure 1 the unemployment rate and the dispersion indicators in relation to graduates' 'own' occupational domain, for each of the six fields or major subjects, are set against each other in order to discover which of these mechanism is actually operative. The figure points in the direction of a positive correlation between the two indicators for the study of medicine. This study has a low unemployment percentage as well as a low SOB coefficient. The explanation is probably that there is sufficient demand for graduates of this study in their 'own' occupational domain. Former students with this study therefore do not have to switch to other occupations so often. The high dispersion coefficients in combination with low unemployment for the major subjects of policy and management of health care services and nursing science indicate many alternative possibilities within as well as outside of the 'own' domain, due to which the unemployment sensitivity of the subjects concerned is low. However, both indicators point at a more difficult labour market position for the study of law. Although their employment is already spread over quite a lot of occupations - often within their 'own' occupational domain - 
unemployment is highest among lawyers. Possibly they find there are insufficient employment opportunities even outside their 'own' occupational domain, which is in itself relatively broad.

Figure 1. Relation between the unemployment rate and the occupational dispersion of the fields of study/major subjects for functions for which the specific study is required

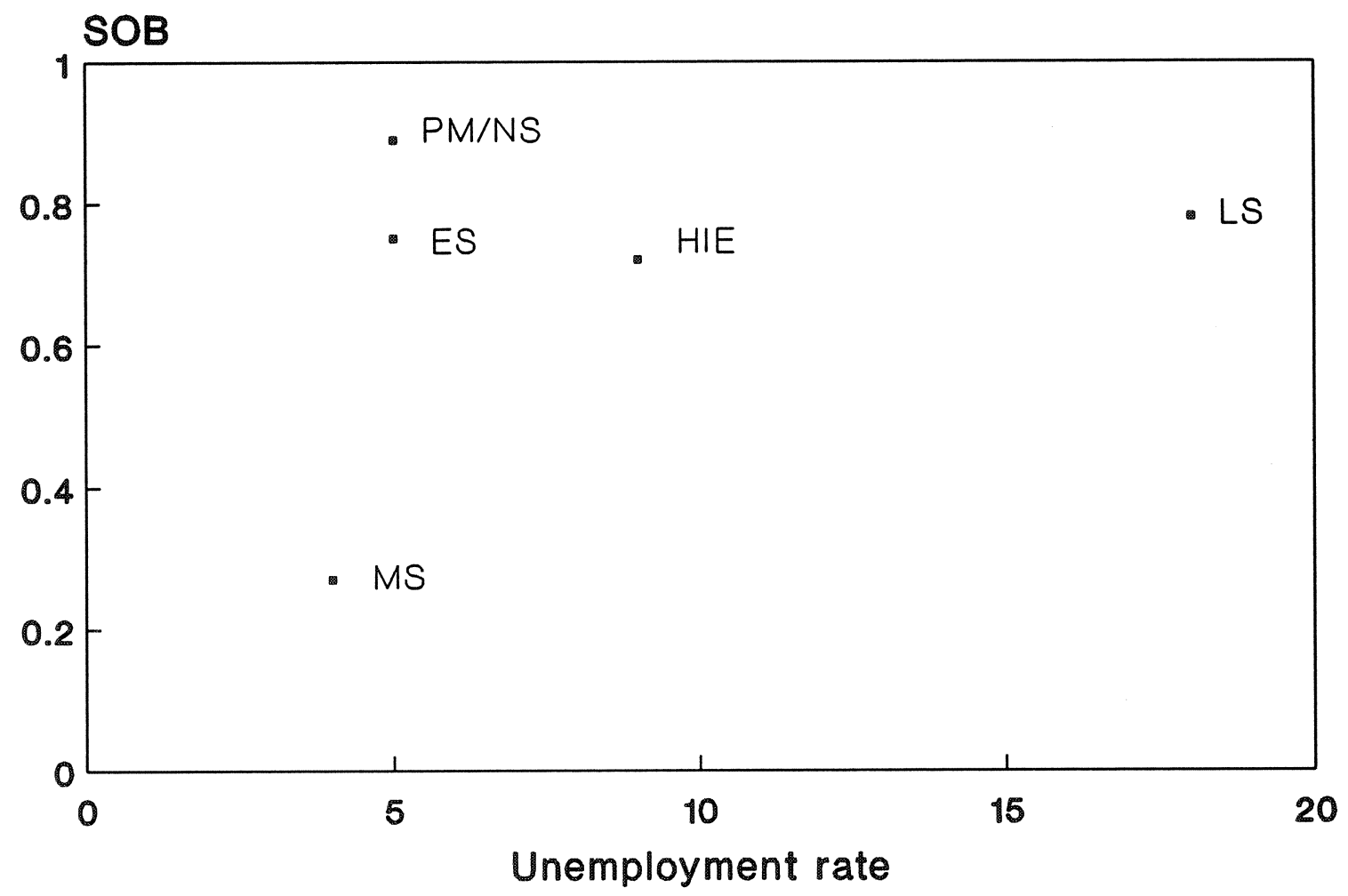

Management

Most respondents did not yet occupy a management function. This is not surprising, since the academics concerned graduated just one to four years ago and are therefore at the start of their professional careers. It can be seen that men were working in management positions significantly more often than women. Of the men, $36 \%$ had a management function, of the women 'only' $22 \%$.

The longer one has been on the labour market, the better the chance of occupying a management position. Of the year ' 89 only $17 \%$ had a managing function; for the year ' 88 it was $26 \%$, for ' 87 it was $31 \%$ and for graduates from the year ' 86 the percentage had already reached $45 \%$. 
Income

Those that had a salaried job were asked for their monthly gross income for full-time work (excluding bonuses for overtime work, a thirteenth month, holiday pay and such). In the questionnaire 9 income classes were distinguished, the lowest and highest of which are 'open'. From the survey results it can be seen that $38 \%$ have a gross monthly income (for a normal working week) that lies within the modal income class of $f 3,750-f 5,000$. The income dispersion is therefore high.

By means of regression analysis we tried to identify the variables, including the study which graduates had taken, which might explain the amount of the gross monthly income for a fulltime work. To this end, each of the observations falling within one the seven 'closed' income classes was assigned the value of the median of the relevant class. Observations in the highest ('open') income class were attributed to the highest closed class. For the lowest ('open') income class the highest possible value was used, being $f 1,500$ gross per month. This comes down approximately to the legal minimum wage.

In the regression equation, personal characteristics and job-related characteristics are used as explanatory variables for the gross monthly income. Dummies were devised for all of these explanatory variables, except for the number of years lapsed after graduation (cohort). The dummy variables relate to the study taken (medicine, economics or law) or the major subject within health sciences (PM, HIE or NS), with the other major subjects within health sciences as a reference category. Further dummies relate to having changed employer (job mobility), male sex (sex), work in a large labour organization (company size), work in the private business sector (profit sector), appointment for an indefinite period (job security), having a full-time job (working time factor), occupying a management function (management), occupying a function for which academic education is a requirement (level requirement) and the combination of working and studying within the function (combi).

As regards personal characteristics, it was assumed that income would differ according to the field of study, that women would have a lower income due to possible discrimination on the labour market, and that income will be higher the longer ago the year of graduation. As for the job characteristics, it was expected that:

- switching jobs would have a positive effect on income;

- a higher function level loccupying a function at academic level and working in a management function) would lead to a higher income;

- a stable job, expressed in an indefinite appointment and a full-time function, would have a positive effect on the monthly income for full-time work;

- the private business sector would pay better than the public sector and larger companies would pay better than the small and medium sized companies;

- 'on the job' training should be seen as an investment in human capital, linked to a lower income now, but which will later lead to a higher income. 
A linear regression comparison was estimated with all the variables, dummy and otherwise, mentioned above. ${ }^{6}$ The estimation results from the regression equation are given in table 9 . The regression coefficients indicate how many guilders the gross monthly income increases by when the explanatory (dummy) variable is 1 . The $t$-values concerned are also mentioned.

Table 9. Results of the regression analysis for gross monthly income

\begin{tabular}{|c|c|c|c|}
\hline & regression & coefficient & $\mathrm{t}$-value \\
\hline Constant & 2318.89 & $* *$ & 11.23 \\
\hline Medicine & 984.57 & $* *$ & 5.49 \\
\hline PM & 417.45 & * & 2.06 \\
\hline HIE & 24.47 & & 0.11 \\
\hline NS & 140.48 & & 0.62 \\
\hline Law & 65.14 & & 0.37 \\
\hline Economics & 18.64 & & 0.07 \\
\hline Cohort & 216.69 & $* *$ & 4.92 \\
\hline Job mobility & 77.55 & & 0.86 \\
\hline Sex & 266.05 & $* *$ & 2.89 \\
\hline Company size & 229.83 & $* *$ & 2.61 \\
\hline Profit-sector & 10.29 & & 0.09 \\
\hline Job security & 454.19 & ** & 4.16 \\
\hline Working hours & 85.04 & & 0.77 \\
\hline Management & 498.14 & $* *$ & 5.04 \\
\hline Level requirement & 304.38 & * & 2.56 \\
\hline Combi & -828.86 & ** & -6.49 \\
\hline Corrected $\mathrm{R}^{2}$ & 0.22 & & \\
\hline Standard error & 1151.62 & & \\
\hline F value & 14.31 & $* *$ & \\
\hline
\end{tabular}

* significant at $5 \%$ level

** significant at $1 \%$ level

The variables included in the regression equation together explain only $22 \%$ of the income variance. Graduates in medicine and former students of the policy and management of health care services (PM) earn a significantly higher income than the reference category. For

6. Probably a logarithmic transformation of income would be preferable, but the graduates have only been on the labour market for a short period and the parameter estimations are now easier to interpret. In any case, the same analysis, conducted after a logarithmic transformation of the income, did not lead to different significance levels for the regression factors. 
physicians the difference is estimated at almost $f 1,000$ gross per month and for PM graduates at over $f \mathbf{4 0 0}$ gross per month. For the other graduates the study taken does not seem to influence the amount of income as compared to the income which the reference category earns.

Furthermore, the analysis shows that the number of years since graduation has an influence on current income: every additional year on the labour market produces over $f 200$ extra income per month. It also appears from the regression analysis that men earn $f \mathbf{2 7 0}$ per month, gross, more than women.

Recently graduated academics who want to acquire a high income should not start working in medium size and small companies. The widespread opinion that the private business sector pays better than the government is not confirmed by the analysis. This does not take into account the fact that the private business sector may offer more inducements in the area of secondary income, for instance in the form of the 'company car', than does the government.

As regards the characteristics of the employment contract, the work time factor has no influence on income but the length of the contract has a positive effect. After translating income to the equivalent for full-time work, it therefore does not make any difference whether one works part-time or full-time. It does appear that in a permanent appointment a significantly higher income can be gained than in a temporary appointment. The difference is estimated at over $f \mathbf{4 5 0}$ gross per month.

The income effect of both function level indicators appears to be significant. As might be expected, working in a management function and occupying a function on a level that matches the educational level have a positive effect on income. People who occupy a management position earn almost $f 500$ gross per month more than those that do not. Academics who occupy a post for which academic education is a requirement earn over $f 300$ gross per month more than those who work below that level.

The influence of job mobility appears not to be significant. The explanation may be that through job mobility one achieves occupational characteristics which in themselves give rise to a higher reward.

Finally it appears that paid work as part of post-graduate training, usually as an assistant in training or assistant-physician in training, is much worse paid. The difference amounts to over $f \mathbf{8 0 0}$ gross per month. Those that combine working with further study will probably consider this low payment an investment in human capital that will bear fruit later on in their professional career. 
In the questionnaire the respondents were asked what the minimum required education was for the function they occupied. If this level is below their academic level, this indicates competition with those educated at another level and under-utilisation of their capacities.

Almost one-fifth of the graduates with paid work performed a function below their academic level. Their capacities are therefore under-utilized. A vast majority however does perform functions meant for academics. This applies in particular to physicians, who were almost exclusively working in functions at an academic level. Of the three groups of health scientists studied in more detail, it was especially former nursing science students $(34 \%)$ and health information and education students $(33 \%)$ who were performing a function below their academic level. For graduates in the policy and management of health care services, $21 \%$ were working below their academic level.

As regards the required level of education, we examined what factors affect the chance of working at an academic level. Six factors were studied.

- The study. For fields of study with a relatively bad labour market position, such as law, the chance of having to switch to a job below one's level of education would be expected to be higher.

- The graduation cohort. The longer one has been on the labour market, the more time there has been for finding a post at a suitable level.

- The sex. The existence of discrimination according to sex may mean that more women than men are forced to switch to jobs below their educational level.

- The sector. A private employer will have more possibilities to accept an over-educated employee than the government with its tightly specified selection criteria.

- The combination of working and learning. It is obvious that in a situation where the filling of a position is combined with 'on the job' study, there is no over-education.

- The instability of the job. If one has a temporary job that is moreover exercised part-time, this points in the direction of a labour market segment with little stability where jobs below one's educational level have to be accepted.

The presence or lack of under-utilization has been expressed in this analysis by a variable that represents the educational requirements of the current function. This variable has the value 1 when academic education is required and there is therefore no under-utilization. The variable has the value 0 if the educational requirements are below the academic level and there is therefore waste. Because the endogenous variables can only have one of two values, a probit model was chosen in which the parameters are estimated with the aid of the maximum likelihood method. The regression factors are also dichotomies (dummies). They have been defined in the same way as for the income analysis, with the addition of the variable job instability, which indicates whether the respondent has a temporary part-time job. On the basis of the hypotheses above, the following signs are expected for the parameters: 
law

other than law

cohort

sex

profit-sector

combi

job instability

Table 10. Estimation results of the probit equation for the probability that academic education is required in the function held

\begin{tabular}{|c|c|c|}
\hline Variable & $\begin{array}{l}\text { Estimated } \\
\text { parameter }\end{array}$ & t-talue \\
\hline Constant & $0.62 *$ & 2.49 \\
\hline Medicine & $1.22 * *$ & 3.60 \\
\hline Economics & 0.20 & 0.50 \\
\hline Law & 0.38 & 1.43 \\
\hline PM & 0.23 & 0.81 \\
\hline HIE & -0.22 & -0.72 \\
\hline NS & -0.31 & -1.02 \\
\hline Cohort & 0.02 & 0.27 \\
\hline Sex & -0.01 & -0.10 \\
\hline Profit-sector & $-0.41 *$ & -2.73 \\
\hline Combi & $1.28 * *$ & 3.05 \\
\hline Job instability & 0.31 & 1.58 \\
\hline
\end{tabular}

* Significant at $5 \%$ level

* * Significant at $1 \%$ level

The estimation results from the analysis are given in table 10. This table shows that the incidence of under-utilization in the private business sector is significantly larger than with the government. Furthermore, significantly more of the academics who continue studying on the job do this in jobs for which an academic education is required. The incidence of underutilization is therefore - in accordance with our hypothesis - greater in jobs where working is not combined with studying.

The expected effect due to differences between fields of study does not actually occur. For the 
field of law, which has the highest proportion of unemployed graduates (see table 8), no significant negative effect was found. This could mean that the degree of unemployment in a certain field of study offers insufficient explanation for the switching of graduates from that field to jobs below their educational level. This could be examined more closely, for instance by including in the analysis the individual's unemployment duration before gaining the post now held. Furthermore, the assumed causality direction could be playing tricks here. Graduates who are no longer looking for a suitable position but accepting a job below their own level will directly reduce the unemployment.

The fact that we did not find a negative correlation between unemployment and finding a job at academic level, together with the finding that the only field having a significant effect was medicine, and this was moreover a positive effect, could also indicate that it is not the degree of unemployment but the degree of exclusiveness of the relation between education and occupation which determines the likelihood of switching to jobs below the educational level (witness the very low SOB coefficient for medicine in table 8).

The results also show that no significant influence on under-utilization could be established for the variables cohort, sex and job instability.

\section{Potential job mobility}

Among this population of recent graduates, the potential job mobility is rather high. Almost onethird $(29 \%)$ of the paid workers are looking for another job. There are significant differences between the branches of study, with physicians looking for another job most often $140 \%$ of the paid workers) and economists the least often (8\%). Health scientists and lawyers occupy a position in between with $27 \%$ and $23 \%$ respectively. Linking up with this, the graduates of the economically-oriented option 'policy and management of health care services' variant within health sciences were less often intending to change jobs $(20 \%$ is looking for another job) compared to former nursing science students $(28 \%)$ and former health information and education students $(29 \%)$.

The likelihood of a graduate looking for another job has been estimated using a probit model. Three background characteristics and seven job-related characteristics were inserted in the estimation equation as explanatory variables for the potential job mobility. The background characteristics concern sex, the field of studies followed and the number of years since graduation. The job-related characteristics relate to the level of the job (the degree to which the job matches the study, the income earned and whether this is a management function), the job stability (number of hours worked and duration of the appointment), the economic sector in which the job is found and whether or not there is a combination of work and on the job training.

We expected to find that a low function level (low income, non-management and a poor match with education) and a less stable job (part-time work and a temporary job) will provide more 
motivation for looking for a new job than a higher function (high income, managerial and a good match) and with a stable employment contract (full-time job, permanent appointment). Furthermore, it is assumed that the likelihood of wanting to change jobs is higher:

- for women, because women as a result of unequal opportunities can be forced to accept jobs that are not their first choice and are therefore more likely than men to be looking for another job;

- the more recently one has graduated, because the longer one has been on the labour market, the more time one has had to find a suitable job. One will be less prone to look for another job;

- when one works for the government, because a private employer has more scope to make a job attractive with inducements in secondary labour conditions, than does the government, with its strict labour conditions. Therefore working for the government can stimulate mobility;

- when working is not combined with on the job training, because recently graduated academics who are learning on the job will have a motivation to complete their training in order to strengthen their future labour market position. Until they have completed their training they will therefore not so often be looking for another job.

All variables have been defined in the same way as in the income analysis and the underutilization analysis, except for income and the required education, which have been operationalized as follows. Income has been operationalized by numbering the nine classes upwards from 1 to 9 . The education required for the function is operationalized in proportion to the degree of match, with the value 1 indicating that no education at academic level is required, the value 2 that only an education at academic level is required and the value 3 that the field of study taken was specifically required.

The endogenous variable 'potential job mobility' has the value 0 if the respondent is not looking for another job and 1 if he or she is. Since the endogenous variable can only have one of two values, a probit model was chosen here as well, in which the parameters were estimated with the aid of the maximum likelihood method. On the basis of the hypotheses given above and the way in which the variables were defined, negative signs are expected for all the parameters that do not relate to the education taken. The estimation results of the analysis are shown in table 11.

From the estimation results it can be seen that employers who give academics a temporary contract or who ask them to work in a position that does not match up well with their education, run a significantly higher risk that these employees will leave. On the other hand, employees who undertake on the job training apparently want to finish this, since with the combination of work and study, the proportion of employees looking for another job appears to be significantly smaller.

Furthermore, physicians are more often looking for another job than are other graduates. The explanation for this result is probably that they are looking for a training post as medical 
specialists (including as a GP or medical officer) while in a job which they have accepted in the meantime. The variables for the number of years since graduation, sex, working in the profit sector, hours of work, managerial functions and income could not be shown to have any significant effect on the

propensity to change job.

Table 11. Estimation results from the probit equation relating to the potential job mobility

$\begin{array}{llr}\text { Variable } & \text { Estimated } & \text { t-value } \\ & \text { parameter } & \\ \text { Constant } & & 1.64 \\ \text { Medicine } & 0.55 & 2.99 \\ \text { Economics } & & 0.76^{* *} \\ \text { Law } & \text { a) } & -0.23 \\ \text { PM } & -0.06 & -1.06 \\ \text { HIE } & -0.29 & -0.55 \\ \text { NS } & -0.16 & -0.93 \\ \text { Cohort } & -0.28 & -0.22 \\ \text { Sex } & & -0.14 \\ \text { Profit-sector } & -0.01 & -1.73 \\ \text { Combi } & -0.02 & -5.20 \\ \text { Job security } & & -2.09 \\ \text { Work time factor } & -0.27 & -1.63 \\ \text { Management } & -0.87^{* *} & 1.91 \\ \text { Match } & -0.30^{*} & -2.92 \\ \text { Income } & -0.24 & -1.64\end{array}$

* Significant at $5 \%$ level

* Significant at $1 \%$ level

a) no parameter estimate indicated because of the very low level of potential job mobility among economists 


\section{SOME POLICY IMPLICATIONS}

The results presented in this article relate to the labour market position of, thus far, four years of RL graduates. This first application of the labour market scanner has initiated the process of mapping the career paths of subsequent cohorts of graduates. A longitudinal approach will however only really be possible when the labour market scanner has been applied over a longer period of time. The market position of more cohorts and their careers over a longer period can then be traced. Moreover, it will then be possible to examine certain questions as regards the match between function and education in more depth. An expanded form of the standard survey could be used for this purpose, applied at five year intervals.

Nevertheless, we are already in a position to point out some areas in which the research results, which this paper has partially reported, could sensibly be used as a basis for making policy decisions. The most we can do is suggest the domains in which these choices are possible. The responsibility for making such decisions and putting them into practice of course rests elsewhere. These decisions are in areas of direct interest to students or to faculty policy makers. The policy measures aimed at students are in the fields of occupational information and planning the work-experience component of study and, for prospective graduates, in the field of labour market orientation, job application strategies and career advice. The labour market scanner supplies a wealth of empirical information which is necessary to support concrete action in these fields. The policy areas mentioned could be given form in a structure specifically created for the task. In this respect the Career Advisory Centre (LAC) which was initiated at the University of Amsterdam this year could be borne in mind. In the LAC, career guidance is given in a coordinated and structured manner.

Faculty policy makers could be asked to consider whether the picture of occupations and sectors given by the labour market scanner coincides with what they had imagined when developing their programme of study, and whether they want to continue with it or not. As regards lawyers, for instance, we have seen that there are few alternatives outside their 'own' professional domain.

In those cases where substitution by graduates from other fields of study or major subjects is possible, this could give rise to a discussion as to whether a deepening of the qualification profile is desirable, in order to decrease the competition from other studies (reduction of the 'own' professional domain) or whether the professional domain should be enlarged by combining with similar disciplines.

It is important to point out that the study-specific research results presented in this article relate only to the differences in labour market position of fields of study within the RL. A national application of the labour market scanner can therefore be recommended. This would make it possible to draw up national reports, which might cover clusters of academic disciples, divided into fields of study, which would enable the results for one's own institution to be compared. Such an approach would help develop a clearer idea of the extent to which the labour market 
$-29-$

position of graduates is specific to each institution, as opposed to being dominated by the national situation regarding the field of study concerned. As has already been mentioned in the introduction, such a national approach is already used in Higher Vocational Education. 


\section{REFERENCES}

Cox, D.R. and D. Oakes (1984), Analysis of Survival Data, London.

Dam, J.W. van, J.A.M. Heijke and G.W.M. Ramaekers (1989), Ontwerp van een arbeidsmarkt scanner voor academici, ROA-R-1989/2, Maastricht.

Dam, J.W. van, J.A.M. Heijke and G.W.M. Ramaekers (1990), Gecoördineerd arbeids marktonderzoek onder hoger opgeleiden: methodiek en resultaat, in: $U \& H$, vol. 37, 19901991, nr. 2, p. 82-91.

Grip, A. de, and J.W. van Dam (1990), Evaluatie van de RUBS-schoolverlatersenquête 1989, ROA-R-1990/2, Maastricht.

Grip, A. de, and J.A.M. Heijke (1991), De uitwijkmogelijkheden op de arbeidsmarkt. Flexibiliteit versus produktiviteit, Onderzoek van Onderwijs, vol. 20, pp. 6-8.

Heijke J.A.M. (1990), De arbeidsmarkt voor universitaire studierichtingen, Tijdschrift voor Hoger Onderwijs, vol. 8, nr. 3, pp. 107-114.

Hoof, J.J. van, and J. Dronkers (1980), Onderwijs en arbeidsmarkt: een verkenning van de relatie tussen onderwijs, arbeidsmarkt en arbeidssysteem, Van Loghum Slaterus, Deventer.

Ramaekers, G.W.M., and J.A.M. Heijke (1991), Arbeidsmarktscanner Rijksuniversiteit Limburg; afgestudeerden 1986-1989, ROA-R-1991/6, Maastricht.

Sheldon G. (1985), Die berufliche und geographische Flexibilität, Institut für Arbeitsmarkt- und Berufsforschung der Bundesanstalt für Arbeit (IAB), Nürnberg.

Warnken, J. (1986), Zur Entwicklung der 'Internen' Anpassungsfähigkeit der Berufe bis zum Jahre 2000. Projectionen unter den Annahmen der Wachstumzenarien der Prognos-Studie, Mitteilungen aus der Arbeitsmarkt und Berufsforschung, nr. 1, pp. 119-133.

Wielers, R., and W. van Nieuwenhuysen (1990), Determinanten van de arbeidsmarktintrede van academici, Tijdschrift voor Hoger Onderwijs, vol. $8 \mathrm{nr} .3$, pp. 115-121. 